\title{
Psikodrama Grup Uygulamasının Hemşirelik Öğrencilerinin Psikolojik İyi Oluş ve Kendini Kabul Düzeyleri Üzerine Etkisi: Yarı Deneysel Bir Çalışma
}

The Effect of Psychodrama Group Practices on Nursing Students Psychological Well-Being, and Self-Acceptance: A Quassi Experimental Study

\section{Yunus KAYA[1] Ebru GÜÇ[2] Bircan KIRLANGIÇ ŞİMŞEK [3] Nilüfer UYAR[4]}

Başvuru Tarihi:14 Aralık 2021

Kabul Tarihi:03 Şubat 2022

Bu çalışma, psikodrama grup uygulamasının hemşirelik öğrencilerinin psikolojik iyi oluş ve kendini kabul düzeyi üzerine etkisini değerlendirmek amacıyla gerçekleştirilmiştir. Yarı deneysel desene göre planlanan bu çalışma, ön-test, son-test ve izlem-testi ölçümleri yapılarak gerçekleştirilmiştir. Çalışma verileri, Demografik Bilgi Formu, Psikolojik İyi Oluş Ölçeği ve Koşulsuz Kendini Kabul Ölçeği aracılığı ile toplanmıştır. Bu çalışma, 14'ü deney grubunda ve 15'i kontrol grubunda olmak üzere toplamda 29 katılımcı ile gerçekleştirilmiştir. Psikodrama grup uygulamasının deney grubunda yer alan katılımcıların Psikolojik İyi Oluş Ölçeği alt boyutlarından "Diğerleri ile Olumlu İlişkiler", "Yaşam Amaçları" ve "Öz Kabul" düzeyleri üzerinde pozitif yönde anlamlı etkisinin olduğu bulunurken, "Koşulsuz Kendini Kabul” düzeyleri üzerinde anlamlı bir etkisinin olmadığı bulunmuştur. Kontrol grubundaki katılımcıların ölçek puan ortalamalarında ise aynı dönemde anlamlı bir değișim olmadı̆̆ı bulunmuștur. Psikodrama grup uygulamasının hemşirelik öğrencilerinin psikolojik iyi oluşları üzerinde anlamlı etkisinin olduğu bulunmuştur. Ancak daha fazla sayıda oturum içerecek şekilde psikodrama oturumlarının gerçekleştirilmesi ile öğrencilerin psikolojik iyi oluşları ve kendini kabul düzeyleri üzerinde önemli etkiler olacağı düşünülmektedir.

Anahtar Kelimeler: hemşirelik öğrencileri, kendini kabul, psikolojik iyi oluş, psikodrama, ruh sağlı̆̆

Received Date:14 December 2021

ABSTRACT

Accepted Date:03 February 2022

This study aims to investigate the effects of psychodrama group practice on nursing students levels of psychological well-being and self-acceptance. This study was planned according to a quasi-experimental design and was carried out pre-test, post-test and followup-test measurements. The study data were collected using the Demographic Information Questionnaire, the Psychological Well-Being Scale, and the Unconditional Self-Acceptance Scale. This study was carried out with a total of 29 participants, 14 in the experimental group and 15 in the control group. While psychodrama group practice had a positive and significant effect on the levels of "Positive Relations with Others", "Life Goals" and "Self-Acceptance" sub-dimensions of the Psychological Well-Being Scale of the participants in the experimental group, it was found that it did not have a significant effect on the unconditional self-acceptance levels. It was found that there was no significant change in the mean scores of the participants in the control group in the same period. It was found that psychodrama group practice had a significant effect on the psychological well-being of nursing students. However, it is thought that conducting psychodrama sessions with more sessions will have significant effects on students' psychological well-being and selfacceptance levels.

Keywords: nursing students, self-acceptance, psychological well-being, psychodrama, mental health https://doi.org/10.47793/hp.1036412

[1] Dr. Öğr. Üyesi | Aksaray Üniversitesi | Sağllk Bilimleri Fakültesi | Aksaray | Türkiye | ORCID: 0000-0003-1665-0377 | yuunus.kaya@gmail.com

[2] Arş. Gör. | Siirt Üniversitesi| Eğitim Bilimleri Fakültesi | Rehberlik ve Psikolojik Danışmanlık Anabilim Dalı| Siirt | Türkiye | ORCID: 0000-0001-7396-9566

[3] Psikolog | Dr. Abdülkadir Özbek Psikodrama Enstitüsü | Ankara | Türkiye | ORCID: 0000-0003-3949-7029

[4] Öğr. Gör. | Anadolu Üniversitesi | Eğitim Fakültesi | Rehberlik ve Psikolojik Danışmanlık Anabilim Dalı | Eskişehir | Türkiye| ORCID: 0000-0003-2653-5049 


\section{GíRİs}

$\ddot{U}$

niversite yaşantısı; bireylerin meslek kimliklerini kazandıkları, akademik ve mesleki bilgi ve becerilerini geliştirdikleri gelişimsel bir süreçtir. Üniversite yaşantısında, bireyler akademik ve mesleki becerilerini geliştirmelerinin yanında ruhsal, sosyal ve kültürel alanlarda meydana gelen değişimle aileden ayrışarak özerkliklerini kazanmakta, kendilerini ve yeteneklerini tanımakta, kişilerarası ilişkilerini geliştirmekte, yaşam hedefleri oluşturmakta ve tüm bu gelişim basamakları doğrultusunda kendilerini keşfetmektedirler (Atak, 2011; Erdoğan vd., 2005; Huang vd., 2018). Bu gelişimsel süreç, her birey için farklı olabilmektedir. Bazı bireyler bu süreci daha sağlıklı biçimde, kendilerine güvenerek, akranlarıyla sağlıklı ilişkiler kurarak ve akademik kariyerleri için planlar yaparak yerine getirmektedir. Bazı bireyler için ise üniversite yaşantısı ruhsal ve soysal zorlanmalara neden olarak gelişimsel bir kriz haline gelebilmektedir. $\mathrm{Bu}$ gelişimsel süreçte yaşanan ruhsal ve sosyal zorlanmalar öğrencilerin psikolojik iyi oluşlarını olumsuz etkileyebilmektedir. Öğrencilerin psikolojik iyi oluşlarında meydana gelen sorunlar, üniversiteye uyum ile ilişkili sorunlara, akademik başarısızlığa, üniversite eğitiminin yarım kalmasına, psikososyal işlevsellikte bozulmaya ve erken dönemde müdahale edilmediğinde akut ya da kronik ruhsal sorunlara yol açabilmektedir (Demirel-Adagide vd., 2011; İlhan vd., 2014; Lee ve Kim, 2019; Tunç vd., 2020).

Psikolojik iyi oluş kavramı ile ilgili alan yazın değerlendirildiğinde Ryff (1995) tarafından geliştirilen psikolojik iyi oluş modelinin son yıllarda yapılan çalışmalarda ve farklı disiplinlerde kullanıldığı görülmektedir (Bewick vd., 2010; Burris vd., 2009; Çelik vd., 2014; İlğan vd., 2015; Kaya ve Deniz, 2020). Ryff'a (1995) göre psikolojik iyi oluş; ruhsal hastalıkların olmamasından ziyade kişinin kendisini nasıl algıladı̆̆ı, yetenek ve potansiyeline yönelik tutumu, kendisinden memnuniyet düzeyi, yaşama yönelik anlam ve amacının olması, diğerleri ile kurduğu ilişkiler, bu ilişkilerden duyduğu memnuniyet, karşılaștığı sorunlar ve bu sorunlarla baş etme yöntemi şeklinde tanımlanmaktadır. Özetle, psikolojik iyi oluş bireyin güçlü bir benlik algısına sahip olması ve sahip olduğu potansiyeli en üst düzeyde kullanmasıdır. Ryff'ın oluşturduğu psikolojik iyi oluş modeli; kendini kabul, yaşam amacı, diğerleriyle olumlu ilişkiler, özerklik, çevrenin yönetimi ve kişisel gelişim olmak üzere altı boyuttan oluşmaktadır (Manderscheid vd., 2010; Ryff, 2017; Ryff ve Keyes, 1995; Ryff ve Singer, 2008).

Psikolojik iyi oluşun alt boyutlarından birisi olan koşulsuz kendini kabul; bireylerin kişisel sınırlıklarının ve güçlü yönlerinin farkında olarak kendisini kabul etme, sahip olduğu sınırlılıklarını yetersizlik ve suçluluk duygusuna kapılmadan kabul etme ve kendine yönelik olumlu tutum içerisinde olma halidir. Ruh sağlığının önemli bir bileşeni olan koşulsuz kendini kabul, bireyin sahip olduğu özellikleri gerçekçi bir bakış açısıyla değerlendirmesi ve sosyal onaylanma ihtiyacı olmaksızın var olan șekliyle kendini kabul etmesi olarak tanımlanmaktadır 
(Chamberlain ve Haaga, 2001; Ellis, 1973). Bu bağlamda, koșulsuz kendini kabul, bireylerin sahip olduğu olumlu ve olumsuz tüm özelliklerini kabul edip, suçluluk ve yetersizlik duygusu hissetmeden değişmeye ve gelişmeye açık yönlerini fark ederek davranış örüntülerini değiştirmesidir. Koşulsuz kendini kabulü yüksek olan kişilerin özellikleri değerlendirildiğinde, yaşam amaç ve hedefleri doğrultusunda özerk davranması, yüksek düzeyde psikososyal işlevsellik göstermesi, benlik saygısının yüksek olması, kaygı ve depresyon düzeylerinin düşük olması ve psikolojik iyi oluşun yüksek olması beklenmektedir (Chamberlain ve Haaga, 2001; Faustino vd., 2020; Macinnes, 2006; Thompson ve Waltz, 2008). Sonuç olarak, bireylerin koşulsuz kendini kabul düzeyleri ve psikolojik iyi oluşları arasında önemli bir ilişki bulunduğunu söylemek mümkündür. Koşulsuz kendini kabul ve psikolojik iyi oluşları yüksek olan kişiler, yaşamda anlam ve amaç duygusuna sahip, olumlu ve başarılı ilişkiler kurabilen, yaşamda karşılaştığı sorunlara yönelik sahip olduğu çözüm yollarını ve baș etme becerilerini kullanabilen, bireysel potansiyelinin farkında olan ve bu farkındalıkla özerk davranışlarda bulunabilen kişiler olarak tanımlanabilir (Manderscheid vd., 2010; Ryff ve Keyes, 1995; Ryff ve Singer 2008; Ryff, 1995; Ryff, 2014; Ryff, 2017). Bu bağlamda, üniversite öğrencilerinin içinde bulundukları gelişimsel dönemde meydana gelen değişimler ve gelişimsel süreçte yaşanan zorluklar hem psikolojik iyi oluşlarını hem de koşulsuz kendini kabul düzeylerini etkileyebilmektedir.

Ergenlik döneminin sonlarına doğru dahil olunan üniversite yaşantısı psikolojik iyi oluş modeli bağlamında değerlendirildiğinde; bireyin kendi yetenek ve potansiyelini tanıdığı, yeni akran gruplarına katıldığı ve kendisi için önemli olan diğerleri ile yakın ilişkiler kurmaya başladığı bir dönem olduğu göze çarpmaktadır. Bireyin bu yeni gelişimsel süreç içerisinde gelişimsel rol ve sorumluluklarını yerine getirebilmesi, karşılaştığı sorunlara çözümler üretmesi, problem çözme ve baş etme becerilerini kazanması, özerkliğini geliştirmek adına denemeler yapabilmesi ve yaşam amaçları oluşturabilmesi için zaman zaman desteklenmeye gereksinimi vardır (Aștı vd., 2005; Huang vd., 2018; Kaya vd., 2021; Tunç vd., 2020). Çünkü üniversite yaşantısı her bir birey için aynı olmamakla birlikte çoğu birey bu süreç içerisinde sorunlar yașayabilmekte, yașanan sorunlar içselleştirilerek kronikleşmekte ve ruhsal sorunların oluşması için alt yapı oluşturabilmektedir (Faustino vd., 2020; Lee ve Kim, 2019; Tunç vd., 2020). Bu nedenle, üniversite öğrencilerinin bu geçiş döneminde kendini ve yeteneklerini tanıma, olumlu benlik algısı geliştirme, sorun çözme becerileri kazanma ve psikolojik iyi oluşun devamlılığını sağlamaya yönelik birtakım koruyucu ruh sağlığı uygulamalarına gereksinimleri vardır (Abbasi vd., 2021; Kaya vd., 2021; Tunç vd., 2020). Söz konusu koruyucu ruh sağlığı uygulamalarına bir örnek de psikodrama temelli grup uygulamalarıdır.

Psikodrama, bireylerin yaşadıkları sorunları sadece konuşmak yerine bu sorunları grup ortamında sahneleyebildikleri, sorun temelli yaşanan yoğun duygularını ifade edebildikleri, diğer 
grup üyelerinin yaşantı, deneyim ve paylaşımlarından karşılıklı öğrenebildikleri ve yaşamlarını prova etme şansı yakaladıkları eyleme dayalı bir grup psikoterapisi yöntemidir. Grup üyeleri, psikodrama sahnesinde geçmiş yaşantılarında deneyimledikleri ancak çözüme kavuşturamadıkları ve/veya farkında olarak ya da olmadan sorun olarak devam eden geriletici izleri "şimdi ve burada" onarıcı bir şekilde yeniden yaşantılama olanağı bulabilmektedir. Aynı zamanda, gelecek yaşamları ile ilgili kaygı ve korkularını da sahneye aktararak gelecek yaşamlarını prova edebilmektedirler (Kellermann, 2013; Özbek ve Leutz, 1987). Bu bağlamda, psikodrama grup uygulamaları, grubun tüm terapötik ilkelerinin aktive olduğu bir süreç olmasının yanında bireylere kendi yaşamları ile ilgili farkındalık, problem çözme ve kişisel güçlenme fırsatı sunmaktadır (Wheeler, 2020).

Üniversite yaşantısında meydana gelen birçok gelişimsel sorumluluk, değișen yaşam koşulları, akademik sorumluluklar ve kişilerarası ilişkiler öğrencilerin zorlanmalarına yol açabilmektedir. Öğrencilere uygulanacak koruyucu ruh sağlığı uygulamalarının öğrencilerin kendini ve yeteneklerini tanıma, özerk davranışlarda bulunabilme, günlük yaşamda ve kişilerarası ilişkilerde problem çözme becerileri geliştirme, yaşam amaç ve hedefleri oluşturmada önemli etkisinin olacağı düşünülmektedir. Koruyucu ruh sağlığı uygulamalarından birisi de psikodrama temelli grup psikoterapi uygulamalarıdır. Ancak psikodrama temeli grup psikoterapilerinin etkinliğini değerlendiren deneysel çalışmalar sınırlı düzeydedir. Bu nedenle, bu çalışmada psikodramanın hemşirelik öğrencilerinin psikolojik iyi oluş ve kendini kabulleri üzerindeki etkisi değerlendirilmiştir. Bu açıdan bu araştırmanın amacı, psikodrama grup uygulamasının hemşirelik öğrencilerinin psikolojik iyi oluşve kendini kabul düzeyleri üzerindeki etkisini değerlendirmektir. Araştırmanın amacı doğrultusunda, aşağıdaki sorulara yanıt aranmıştır;

1. Deney grubundaki katılımcıların ön-test, son-test ve izlem-testinde psikolojik iyi oluş ve koşulsuz kendini kabul puan ortalamaları arasında farklılık var mıdır?

2. Kontrol grubundaki katılımcıların ön-test, son-test ve izlem-testinde psikolojik iyi oluş ve koşulsuz kendini kabul puan ortalamaları arasında farklılık var mıdır?

3. Deney ve kontrol grubundaki katılımcıların ön-test, son-test ve izlem-testinde psikolojik iyi oluş ve koşulsuz kendini kabul puan ortalamaları arasında farklılık bulunmakta midır?

\section{YÖNTEM}

\section{Araştırmanın Modeli}

Bu çalışma, ön-test, son-test ve izlem-testinin uygulandığı, randomize olmayan, kontrol gruplu ve yarı deneysel bir çalışmadır (Büyüköztürk, 2016). 


\section{Çalışma Grubu}

Çalışma, Türkiye'de bir üniversitenin hemşirelik okulu bünyesinde gerçekleştirilmiştir. Çalışma verileri, Mart-Temmuz 2019 tarihleri arasında 16'sı deney 16'sı kontrol grubunda olmak üzere toplamda 32 katılımcıdan ön-test, son-test ve izlem-testi uygulaması yapılarak toplanmıștır. Araştırmacılar, hemşirelik öğrencilerine yönelik psikodrama grup uygulaması duyurusunu okulda tüm öğrencilerin görebileceği alanlara afişler asarak ilan etmişlerdir. Katılımcıların öncelikle e-posta ya da bireysel yolla başvuruları alınmış ve başvurular sürecinde katılımcılara grup uygulamasına başlanmadan önce her bir katılımcı ile ön görüşmelerin yapılacağı bildirilmiștir. Bașvuru sırası doğrultusunda iki araștırmacı tarafından her bir katılımcı ile ön görüşme gerçekleștirilmiștir. Ön görüşmede iki taraflı bir değerlendirme yapılmıștır. Araștırmacılar, aday katılımcıların gruba uygunluğunu değerlendirirken katılımcıların ise gruptan beklentileri, gruba geliş amaçları ile yapılacak psikodrama grubunun amacının örtüşmesi, belirtilen grup çalışma yöntemleri ve çalışma saatleri açısından gruba dahil olup olmayacağına yönelik bir karar vermesi beklenmiştir. Gruba katılmaya karar veren katılımcılar, grup ve çalışma kurallarının yer aldığı ön sözleşme formunu okumuş ve katılmayı kabul eden katılımcılar ön sözleşme formunu imzalamışlardır. Ön görüşme sonrasında, grubun etkin yönetilebilmesi adına gruba katılmaya gönüllü olan 16 katılımcı deney grubuna dahil edilmiştir. Deney grubundaki katılımcıların sosyodemografik özellikleri dikkate alınarak ve gruplar arası farklılığın önlenmesi amacıyla kontrol grubuna 16 katılımcı dahil edilmiştir. Çalışmaya dahil edilmede, hemşirelik öğrencisi olma, herhangi bir ruhsal bozukluğa ya da zihinsel yetersizliğe sahip olmama ve çalışmaya gönüllü olarak katılma kriteri aranmıştır.

\section{Veri Toplama Araçları}

Çalışma verileri, Demografik Bilgi Formu, Psikolojik İyi Oluş Ölçeği ve Koşulsuz Kendini Kabul Ölçeği aracıllı̆̆ıla toplanmıştır.

Demografik Bilgi Formu. Demografik Bilgi Formu, araștırmacılar tarafından hazırlanmış olup yaş, cinsiyet, sınıf, anne ve baba eğitim düzeyini değerlendirmek üzere beş sorudan oluşmaktadır.

Psikolojik İyi Oluş Ölçeği (PIOÖ). Bu ölçek, Ryff (1989) tarafından, bireylerin psikolojik iyi oluşlarını değerlendirmek amacıyla geliştirilmiştir (Ryff, 1995). Ölçeğin Türkçe geçerlik ve güvenirlik çalışması Akın (2008) tarafından yapılmıştır. PİOÖ, psikolojik iyi olma modelini temel alarak, Özerklik, Çevresel Hakimiyet, Kişisel Gelişim, Diğerleriyle Olumlu İlişkiler, Yaşam Amaçları ve Öz Kabul olmak üzere altı alt boyuttan oluşmaktadır. Her bir alt boyut 14 sorudan, toplam ölçek 84 sorudan oluşmaktadır. Ölçeğin her bir maddesi için verilecek yanıtlar "Hiç Katılmıyorum" (1) ile "Tamamen Katılıyorum" (6) arasında değişmektedir. Ölçekten alınabilecek en düşük puan 84 
en yüksek puan ise 504'dür. Ölçekten alınan puan arttıkça katılımcıların psikolojik iyi oluşları artarken, ölçekten alınan puan azaldıkça psikolojik iyi oluşlarının azaldığı şeklinde yorumlanmaktadır. Orijinal ölçeğin Cronbach Alfa değerleri .86 ile .93 arasında değişirken, Türkçe formunun Cronbach Alfa değerlerinin .87 ile .96 arasında değiştiği bulunmuştur. Bu çalışma için ise Cronbach Alfa değeri toplam puan için .90 olarak bulunurken alt boyutların Cronbach Alfa değerleri .77 ile .94 arasında değiștiği bulunmuştur.

Koşulsuz Kendini Kabul Ölçeği (KKKö). Chamberlain ve Haaga (2001) tarafından geliştirilen KKKÖ’nün, Türkçe geçerlik ve güvenirlik çalışması Acun-Kapıkıran ve Kapıkıran (2010) tarafından gerçekleştirilmiştir. Orijinal ölçek 20 sorudan oluşurken Türkçe geçerlik ve güvenirlik çalışması sürecinde bir maddenin çıkartılmasıyla ölçeğin son hali 19 sorudan oluşmaktadır. Katılımcıların, her bir soruya vereceği yanıtlar "Hemen her zaman geçersiz" (1) ile "Hemen her zaman geçerli" (7) arasında değişen yedili Likert tipi ölçüm aracıdır. Ölçek koşullu ve koşulsuz kendini kabulü değerlendiren iki alt boyuttan oluşmaktadır. Ölçek maddelerinden 12 madde koşullu kabulü değerlendirirken, 7 madde de koşulsuz kabulü değerlendiren sorudan oluşmaktadır. Olumsuz maddelerin ters çevrilerek puanlaması ile koşulsuz kendini kabulü değerlendiren toplam puan elde edilmektedir. Ölçekten en az 19, en fazla 133 puan elde edilebilmektedir. Ölçekten elde edilen puan arttıkça katılımcıların kendilerini koşulsuz kabul etme düzeyi artmaktadır. Orijinal ölçeğin Cronbach Alfa değeri .72, Türkçe formunun Cronbach Alfa değeri .76, bu çalışma için Cronbach Alfa değeri .78 olarak bulunmuştur.

\section{Veri Toplama Süreci}

Deney grubu için psikodrama oturumları, Nisan-Mayıs 2019 tarihleri arasında 10 oturum şeklinde gerçekleștirilmiştir. Her bir oturum ortalama 150-165 dakika arası sürmüştür. İlk beş oturum hem grup üyelerinin birbirini tanıması ve grup bağlılığının oluşması hem de katılımcıların grup yaşantılarını içselleştirmesi için haftada bir gün şeklinde çalışılırken, son beş oturum haftada iki oturum yapılarak gerçekleștirilmiștir. Psikodrama gruplarına başlamadan önce hem deney hem de kontrol grubundan ön-test verileri toplanmıștır. Grup uygulaması bittikten sonra her iki gruptan da son-test verileri toplanmıștır. Son test verileri toplandıktan iki ay sonra (Temmuz 2019) hem deney hem kontrol grubundaki katılımcılardan izlem-testi verileri toplanmıştır. Öntest uygulaması sırasında katılımcılardan soru formları üzerinde bir rumuz belirtmeleri, son-test ve izlem-testinde bu rumuzları tekrardan formlarına yazmaları istenmiştir. Deney grubu ile gerçekleştirilen psikodrama grubuna 16 katılımcıyla başlanmış, katılımcılardan ikisi birinci oturumdan sonra gruptan ayrılmak istediğini belirtmiștir. Böylelikle deney grubu 14 katılımcı ile tamamlanmıştır. Kontrol grubundaki bir katılımcı izlem-testindeki soruları eksik yanıtladığı için çalışma dışı bırakılmış ve kontrol grubu 15 katılımcı ile tamamlanmıştır. Çalışma verilerinin toplandığı tüm basamaklarda katılımcılardan yazılı onam alınmıştır. 


\section{Grup Müdahalesi}

Psikodrama grup oturumları, birinci ve ikinci yazarlar tarafından yürütülmüștür. Birinci yazar grup oturumlarını yönetmiş, ikinci yazar grup oturumlarında yardımcı yöneticilik yapmıştır. Yardımcı yönetici hem grup oturumlarında notlar almış hem de grup üyelerinin eksik olduğu ve/veya ihtiyaç olduğunda grup oyunlarında rol almıştır. Aynı zamanda her oturum öncesi ve sonrasında yönetici ve yardımcı yönetici bir araya gelerek grubu değerlendirmiștir ve grup oturumları sonrasında yardımcı yönetici grup yöneticisine akran geribildirimi vermiştir. Her oturum sonrasında birinci yazar tarafından yazılı hale getirilen grup oturumlarına üçüncü yazar hem yazılı hem de telefon yoluyla süpervizyon, dördüncü yazar ise akran geri bildirimi vermiştir. Yönetici, yardımcı yönetici ve akran geribildirimi veren yazarlar hem psikodrama ileri aşama öğrencisidir hem de daha öncesinde psikodrama grup çalışmaları gerçekleştirmişlerdir. Süpervizyon veren yazar ise psikodrama eğiticisidir.

Psikodrama; 1sınma, grup oyunları, protagonist oyunu ile her bir oyundan sonra özdeşim ve yaşantı paylaşım süreçlerinin yer aldığı eyleme dayalı bir grup terapisidir (Kellermann, 2013). Deney grubundaki katılımcılarla, kendini tanıma, kişilerarası ilişkileri yönetme, yaşamda amaç oluşturma ve kendini kabul üzerine ısınma ve grup oyunları, gönüllü olan katılımcılarla protagonist oyunları gerçekleştirilmiştir. Kontrol grubundaki katılımcılara ise herhangi bir girişimde bulunulmamıştır. Deney grubu ile gerçekleştirilen 10 oturumluk psikodrama grubunda aşağıda verilen başlıklar ve içerikler grubun spontanlığına ve gereksinimlerine uygun biçimde çalıșılmıştır. Her bir oturuma başlamadan önce üyelerin hangi duygularla gruba geldiği konuşulmuș, her bir oyundan sonra (ısınma, grup ve protagonist) üyelerin oyunla ilgili paylaşımları alınmıştır. Her bir oturum sonunda üyelere hangi duygularla gruptan ayrıldığı sorularak nasıl ayrıldıkları konusunda bilgi edinilerek ve oturumla ilgili geri bildirim alınarak oturumlar gerçekleştirilmiştir.

Oturum-1. Üyelerin birbirleriyle tanışmasına ve ön görüşmede imzalanan yazılı grup kurallarının daha iyi anlaşılması ve yazılı olmayan ancak ihtiyaç duyulan kuralların oluşturulmasına yönelik grup oyunu oynatılmıştır.

Oturum-2. İki üye gruptan ayrılmak istediğini belirtmiş ve iki üyenin grup sürecinden ayrılmaya yönelik vedası çalışılmıştır. Vedanın ardından üyelerin, grupla ilgili kısa ve uzun vadeli amaçları doğrultusunda grup oyunu oynatılmıştır. Grubun amacı her ne kadar ön görüşmelerde açıklansa da grup yaşantısı başlayınca özellikle başlangıç oturumlarında üyelerin kendi amaçları ve grubun amaçlarını tekrar ve daha somut değerlendirdikleri bilinmektedir. $\mathrm{Bu}$ nedenle bu oturumda kalan üyeler kısa ve uzun vadeli amaçlarını çalışmışlardır. 
Oturum-3. Üyeler ve yönetici arasında; yöneticinin grup dıșında öğretmen rolünün olması nedeniyle tanışıklıkları bulunmaktadır. Bu nedenle söz konusu tanışıklık rollerini dışarda bırakma ve grup yöneticisi rolünde yeni ilişkiyi başlatmak amacıyla yeni rolde tanışma amacıyla grup oyunu oynatılmıştır. Bu oyunla aynı zamanda rol esnekliği kazandırılmaya başlanması da umulmaktadır. Yeniden tanışıklık oyunu ile üyeler kendileri için rumuz bulmuşlardır.

Oturum-4. Genel olarak grup kohezyonunu sağlamak amaçlanmıştır. Bu amaca uygun olarak üyelerle, duygularını fark etmeye yönelik ısınma oyunu, gruptaki yerlerini, rollerini ve grup ismini belirlemeye yönelik grup oyunu oynanmıștır.

Oturum-5. Üyelere, kendilerini tanıma ve kendi özelliklerini keşfetmeye yönelik grup oyunu, sonrasında diğerlerinin duygularını tanımaya yönelik grup oyunu oynatılmıștır.

Oturum-6. Grubun bulunduğu aşamaya uygun olarak, oturuma isınma oyununun ardından, günlük ilişkilerde diğerini yönetmek ve diğeri tarafından yönetilmeye yönelik grup oyunu ve grup içi zorluklar, çatışmalar, grubun gereksinimlerinin neler olduğu ve bu çatışmanın yönetilmesine yönelik grup oyunu oynatılmıştır.

Oturum-7. Üyelere, grup içindeki rolleri, bu rollerin dişardaki yaşamla ilişkisi ve grubun bütün olarak çalışmasına yönelik grup oyunu ve grupla birlikte çalışma, grup içi çatışmalar ve bu çatışmaların çözümüne yönelik grup oyunu oynatılmıştır.

Oturum-8. Grubun bütünleşme aşaması olduğundan grup içi çatışmaların çözülmesi, çözülme umudunun olmasının üyelerin gruba devam etme motivasyonunu, çatışmaları çözme ve nasıl yol alacaklarını belirlemeye yönelik grup oyunu oynatılmıştır.

Oturum-9. İki üyenin gruba kaygiyla geldiklerini belirtmeleri üzerine yönetici iki üyeyi protagonist oyunu için davet etmiştir ve üyelerden birisi ile protagonist oyunu oynanmıștır. Grubun tamamlanma aşamasında olması nedeniyle beklenebilen bir durumdur. Dördüncü oturumda üyelerin bireysel örüntüleri ve bu örüntülerin grup içi rollere yansımasını ortaya çıkaran bir oyun oynatılmıştır. Protagonist oyunu sonrasında, grubun tamamlanma aşamasına yaklaşıldığı için grup içi rollerine yansıyan bireysel örüntülerinde değişiklik olup olmadığını anlamaya yönelik grup oyunu oynanmıștır.

Oturum-10. Üyeler üçüncü oturumda kendilerine buldukları rumuzlara tekrardan bakmaya davet edilmiş, rumuzlarında ve özelliklerinde herhangi bir değişimin olup olmadığına bakmalarına yönelik grup oyunu oynatılmıștır. Sonrasında, grup sürecinde kendileri ile ilgili farkındalıkları ve oluşturdukları yeni amaçlar doğrultusunda kendi masallarını yazmaya yönelik grup oyunu oynatılmıştır. Son olarak üyelerin süreçteki kendilerini değerlendirmeye yönelik grup öncesinde ben, grup bittiğinde ben ve gelecekteki ben temalarına yönelik grup oyunu oynatılmış ve üyeler arasında veda çalıșılmıștır. Bu oturum, grubun terminasyon oturumu olması ve üyelerin 
grup bütünlügünden ayrışarak bireysel olarak yaşamlarına devam edecek olmaları nedeniyle hem ayrışmanın sağlanması hem de geleceğe dönük hedeflerini oluşturmaları ve umutla ayrılmalarını sağlayacak şekilde yönetilmiştir.

\section{Verilerin Analizi}

Çalışma verileri, SPSS 24 paket programı kullanılarak analiz edilmiştir. Katılımcıların, tanıtıcı özellikleri için yüzde, ortalama ve standart sapma değerleri kullanılmıştır. Deney ve kontrol grubu tanıtıcı özelliklerinin karşılaştırılmasında Ki Kare testi kullanılmıştır. Gruplar arası ölçek puan ortalamasının karşılaştırılmasında Mann-Whitney U Testi, grup içi ortalamaların karşılaştırılmasında ise Friedman ve Wilcoxon İşaretli Sıralar Testi $(p<0.05)$ kullanılmıştır.

\section{Etik Onay}

Çalışmanın gerçekleştirilebilmesi için verilerin toplanacağı hemşirelik okulu yöneticilerinden izin alındıktan sonra İnsan Araştırmaları Etik Kurulu'ndan etik onay alınmıştır (25.03.2019 tarihli, 04/582 sayılı). Çalışma verilerinin toplanması sürecinde tüm katılımcılardan yazılı onam alınmıștır.

\section{BULGULAR}

Deney ve kontrol grubunda yer alan katılımclların demografik özellikleri Tablo 1'de yer almaktadır. Deney grubundaki katılımcıların yaș ortalaması $20.57 \pm 1.08$, kontrol grubundaki katılımcıların yaș ortalamaları ise $20.40 \pm 0.91$ olarak bulunmuştur. Deney ve kontrol grubundaki katılımcıların yaş, cinsiyet, sınıf düzeyi, anne ve baba eğitim seviyesi gibi demografik özellikleri arasında farklılık bulunmamıştır $(p>0.05)$. Deney ve kontrol grubundaki katılımcıların demografik özellikleri değerlendirildiğinde katılımcıların büyük çoğunluğunu kadınlar ve ikinci sınıf öğrencilerinin oluşturduğu, katılımcıların anne eğitim seviyelerinin ilköğretim ve altı eğitim seviyesinde olduğu, baba eğitim seviyelerinin ise lise ve altı eğitim seviyesinde olduğu bulunmuştur. 
Tablo 1

Deney ve kontrol grubundaki katılımclların demografik özellikleri $(n=29)$

\begin{tabular}{|c|c|c|c|c|c|}
\hline $\begin{array}{l}\text { Demografik } \\
\text { Değișkenler }\end{array}$ & & $\begin{array}{c}\text { Deney Grubu } \\
(n=14)\end{array}$ & $\begin{array}{c}\text { Kontrol Grubu } \\
(n=15)\end{array}$ & $\begin{array}{c}\text { Test } \\
\text { Değeri }\left(x^{2}\right)\end{array}$ & $p$ \\
\hline Yaş (Ort $\pm S S$ ) & & $20.57 \pm 1.08$ & $20.40 \pm 0.91$ & 1.377 & 0.711 \\
\hline \multirow{2}{*}{ Cinsiyet (\%) } & Kadın & 85.7 & 80.0 & \multirow{2}{*}{.166} & \multirow{2}{*}{0.684} \\
\hline & Erkek & 14.3 & 20.0 & & \\
\hline \multirow{3}{*}{ Sinıf (\%) } & Birinci & 7.1 & 6.7 & \multirow{3}{*}{.024} & \multirow{3}{*}{0.988} \\
\hline & İkinci & 57.2 & 60.0 & & \\
\hline & Üçüncü & 35.7 & 33.3 & & \\
\hline \multirow{4}{*}{ Anne Eğitim (\%) } & Okur-yazar değil & 42.9 & 40.0 & \multirow{4}{*}{4.047} & \multirow{4}{*}{0.400} \\
\hline & İlköğretim & 50.0 & 46.7 & & \\
\hline & Lise & 0.0 & 13.3 & & \\
\hline & Üniversite & 7.1 & 0.0 & & \\
\hline \multirow{4}{*}{ Baba Eğitim (\%) } & Okur-yazar değil & 7.1 & 0.0 & \multirow{4}{*}{5.248} & \multirow{4}{*}{0.263} \\
\hline & İlköğretim & 28.7 & 53.3 & & \\
\hline & Lise & 57.1 & 26.7 & & \\
\hline & Üniversite & 7.1 & 20.0 & & \\
\hline
\end{tabular}

Tablo 2'de deney ve kontrol grubunun, PİOÖ toplam puan ve alt boyutlarının ortalaması ve KKKÖ toplam puan ortalamasının ön-test, son-test ve izlem-testi puan ortalamasının karşılaştırılması verilmiştir. Deney ve kontrol grubu, ön-test, son-test ve izlem-testi puan ortalamaları karşılaştırıldığında; PİÖ toplam ve alt boyutlarının puan ortalaması ve KKKÖ toplam puan ortalaması arasında önemli bir fark olmadığı bulunmuştur ( $p>0.05)$. PİOÖ toplam ve alt boyutlarının puan ortalamaları ve KKKÖ toplam puan ortalamasının deney grubunda kontrol grubuna göre son-test ve izlem-testi puan ortalamaları açısından daha yüksek olduğu ancak bu farkın istatistiksel olarak önemli bir fark olmadığı bulunmuştur ( $p>0.05)$.

Tablo-2'de grup içi ortalamalar arasında önemli bir fark olup olmadığını değerlendirmek için yapılan Friedman testi sonucunda deney grubunda PİoÖ ölçeği alt boyutlarından Diğerleri ile Olumlu İlişkiler, Yaşamdaki Amaçlar ve Öz Kabul puan ortalamalarının farklılaștığı bulunmuştur. Farklılığın hangi ölçümden kaynaklandığını belirlemek için yapılan Wilcoxon İşaretli Sıralar Testine göre Diğerleri ile Olumlu İlişkiler alt boyutu için ön-test ve son-test arasında, Yaşamdaki Amaçlar alt boyutu için son-test ve izlem-testi arasında ve Öz Kabul alt boyutu için ön-test ve izlem-testi arasında olduğu bulunmuştur ( $\mathrm{p}<0.05)$. Deney grubunda, diğer PİOÖ alt boyutlarında, PİOÖ ve KKKÖ toplam puan ortalamasının son-test ve izlem-testinde ön-teste göre arttığı ancak bu farkın istatistiksel olarak önemli fark olmadığı bulunmuștur ( $p>0.05)$. Kontrol grubunda ise grup içi farklılıkları değerlendirmeye yönelik yapılan analizde ölçümler arasında önemli bir farklılığın olmadığı bulunmuştur ( $p>0.05$ ). 


\section{Tablo 2}

Deney ve kontrol grubunun psikolojik iyi oluş ve koşulsuz kendini kabul ölçeği ön test, son test ve izlem testi puan ortalamaları

\begin{tabular}{|c|c|c|c|c|c|}
\hline \multirow[t]{2}{*}{ Ölçüm Araçları } & & $\begin{array}{c}\text { Deney Grubu } \\
(n=14)\end{array}$ & $\begin{array}{c}\text { Kontrol Grubu } \\
(n=15)\end{array}$ & \multirow{2}{*}{$\begin{array}{c}\text { Test } \\
\text { Değeri }\end{array}$} & \multirow{2}{*}{$p$} \\
\hline & & $\mathrm{X} \pm \mathrm{SS}$ & $\mathrm{X} \pm \mathrm{SS}$ & & \\
\hline \multirow{5}{*}{ Özerklik } & Ön test & $63.14 \pm 8.70$ & $57.40 \pm 15.87$ & -1.180 & 0.25 \\
\hline & Son test & $65.21 \pm 8.72$ & $59.62 \pm 14.18$ & -1.093 & 0.27 \\
\hline & İzlem testi & $63.21 \pm 9.45$ & $60.46 \pm 13.19$ & -.524 & 0.60 \\
\hline & Test değeri & 2.073 & 3.733 & & \\
\hline & $p$ & 0.35 & 0.15 & & \\
\hline \multirow{5}{*}{$\begin{array}{l}\text { Çevresel İlişkilerde } \\
\text { Hâkimiyet Kurma }\end{array}$} & Ön test & $58.37 \pm 9.78$ & $55.53 \pm 10.72$ & -.677 & 0.49 \\
\hline & Son test & $62.29 \pm 6.60$ & $56.66 \pm 12.39$ & -1.130 & 0.19 \\
\hline & İzlem testi & $61.45 \pm 6.47$ & $55.36 \pm 14.97$ & -1.245 & 0.21 \\
\hline & Test değeri & 3.000 & 1.536 & & \\
\hline & $p$ & 0.22 & 0.46 & & \\
\hline \multirow{5}{*}{ Kişisel Gelişim } & Ön test & $67.78 \pm 9.03$ & $67.19 \pm 6.96$ & -.612 & 0.54 \\
\hline & Son test & $71.07 \pm 6.76$ & $68.00 \pm 5.02$ & -1.356 & 0.17 \\
\hline & İzlem testi & $72.25 \pm 6.07$ & $66.31 \pm 9.26$ & -1.640 & 0.10 \\
\hline & Test değeri & 3.509 & .667 & & \\
\hline & $p$ & 0.17 & 0.71 & & \\
\hline \multirow{5}{*}{$\begin{array}{l}\text { Diğerleri İle } \\
\text { Olumlu İlişkiler }\end{array}$} & Ön test & $67.10 \pm 7.91^{\mathrm{a}}$ & $65.67 \pm 8.81$ & -.481 & 0.63 \\
\hline & Son test & $70.72 \pm 9.41^{b}$ & $65.46 \pm 9.48$ & -1.486 & 0.13 \\
\hline & İzlem testi & $69.14 \pm 9.21$ & $66.37 \pm 13.29$ & -.263 & 0.79 \\
\hline & Test değeri & 6.778 & 0.138 & & \\
\hline & $p$ & $0.04 \mathrm{a}-\mathrm{b}$ & 0.93 & & \\
\hline \multirow{5}{*}{ Yaşamdaki Amaçlar } & Ön test & $64.21 \pm 9.93$ & $59.46 \pm 11.10$ & -1.158 & 0.24 \\
\hline & Son test & $64.42 \pm 6.66^{b}$ & $61.13 \pm 11.15$ & -.569 & 0.57 \\
\hline & İzlem testi & $68.64 \pm 7.45^{c}$ & $64.73 \pm 13.91$ & -.656 & 0.51 \\
\hline & Test değeri & 7.309 & 5.931 & & \\
\hline & $p$ & $0.02 . \mathrm{b}-\mathrm{c}$ & 0.05 & & \\
\hline \multirow{5}{*}{ Öz Kabul } & Ön test & $57.12 \pm 7.15^{\mathrm{a}}$ & $54.34 \pm 12.55$ & -.786 & 0.43 \\
\hline & Son test & $59.90 \pm 6.57$ & $52.00 \pm 12.86$ & -1.813 & 0.07 \\
\hline & İzlem testi & $61.92 \pm 7.37 \mathrm{c}$ & $54.07 \pm 16.39$ & -.1289 & 0.19 \\
\hline & Test değeri & 8.037 & 5.119 & & \\
\hline & $p$ & $0.01 . \mathrm{a}-\mathrm{c}$ & 0.07 & & \\
\hline \multirow{5}{*}{ Pİö Toplam Puan } & Ön test & $377.74 \pm 35.84$ & $359.62 \pm 50.07$ & -1.004 & 0.31 \\
\hline & Son test & $393.63 \pm 33.57$ & $362.62 \pm 50.07$ & -1.550 & 0.12 \\
\hline & İzlem testi & $391.35 \pm 30.41$ & $362.88 \pm 47.22$ & -1.135 & 0.25 \\
\hline & Test değeri & 1.724 & .712 & & \\
\hline & $p$ & 0.42 & 0.70 & & \\
\hline \multirow{5}{*}{ KKКÖ Toplam Puan } & Ön test & $83.47 \pm 8.49$ & $82.65 \pm 16.19$ & -.219 & 0.82 \\
\hline & Son test & $87.28 \pm 11.85$ & $81.45 \pm 15.71$ & -1.092 & 0.27 \\
\hline & İzlem testi & $85.32 \pm 12.78$ & $80.86 \pm 17.51$ & -.612 & 0.54 \\
\hline & Test değeri & 2.436 & .237 & & \\
\hline & $p$ & 0.29 & 0.88 & & \\
\hline
\end{tabular}




\section{TARTIŞMA, SONUÇ VE ÖNERÍLER}

Bu çalışma, psikodrama grup uygulamasının hemşirelik öğrencilerinin psikolojik iyi oluş ve kendini kabul düzeyleri üzerine etkisini değerlendirmek amacıyla gerçekleştirilmiştir. Elde edilen bulgular alanyazın doğrultusunda tartışılmıştır.

Bu çalışmada, elde edilen sonuçlar değerlendirildiğinde, psikodrama grup uygulamasının hemşirelik öğrencilerinin psikolojik iyi oluş toplam puan ve alt boyutları puan ortalamalarının kontrol grubuna göre arttığı ancak bu değişimin anlamlı olmadığı bulunmuştur. Bununla birlikte, deney grubuna uygulanan psikodrama grup uygulamasının PİOÖ alt boyutlarından Diğerleri ile Olumlu İlişkiler, Yaşamdaki Amaçlar ve Öz Kabul düzeyleri üzerinde zaman içerisinde pozitif yönde anlamlı etkisinin olduğu bulunmuştur. Pİö toplam puan ortalaması ve diğer alt boyut puan ortalamalarının da arttığı, fakat değişimin istatistiksel olarak anlamlı olmadığı bulunmuştur. Alanyazındaki çalışma bulguları değerlendirildiğinde çalışma bulgusunu destekler nitelikte sonuçların olduğu bulunmuştur. Kaya ve Deniz (2020) psikodrama grup uygulamasının üniversite öğrencilerinin psikolojik iyi oluşları üzerindeki etkisini değerlendirdikleri çalışmalarında deney grubunun puan ortalamasının kontrol grubu puan ortalamasına göre arttığı ancak bu farkın istatistiksel düzeyde anlamlı olmadığı sonucuna ulaşmışlardır. Benzer șekilde, Cesur-Atintaş ve Kırlangıç-Şimşek (2020) üniversite öğrencileri ile gerçekleștirdikleri psikodrama grup uygulamasının öğrencilerin psikolojik iyi oluşları üzerinde anlamlı etkisinin olmadığı sonucuna ulaşmışlardır. Kaya (2020) ise psikodrama grup uygulamasının hemşirelik öğrencilerinin öznel iyi oluşları üzerindeki etkisini değerlendirdiği çalışmasında, psikodramanın öğrencilerin kendini ve duygularını tanıma, yaşam amaçlarının oluşturulması üzerinde anlamlı etkisinin olduğu, kendine güven, kişilerarası ilişkileri yönetme ve baş etme üzerinde anlamlı etkilerinin olmadığı sonucuna ulaşmıştır. Karataş (2014) üniversite öğrencilerinin öznel iyi oluş düzeylerine psikodrama grup uygulamasının etkisini değerlendirdiği çalışmasında deney grubundaki katılımcıların "Öznel İyi Oluş" düzeylerinin arttığı sonucunu elde etmiştir. Alanyazındaki bu bulguların aksine, çalışmadaki bu sonucun oturum sayısının az olması ve grup üyelerinin birbirini tanımasının grup sürecinde kendilerini açmaları üzerinde olumsuz etkilere yol açtığı ve psikolojik iyi oluşun toplam puan ortalamaları üzerinde anlamlı değişimleri etkilediği düşünülmektedir. Aynı zamanda, grup oturumlarında çalışılan temaların birey tarafından işlemlenmesi ve içselleştirilmesinin kısa zaman diliminde gerçekleşmeyecek olması ve ölçümlerin birbirine yakın zaman dilimlerinde yapılmasının puan ortalamaları üzerinde etkili olduğu düşünülmektedir.

Bu çalıșmada, psikodrama grup uygulamasının hemșirelik öğrencilerinin kendini kabul düzeyleri üzerindeki etkisi değerlendirildiğinde deney grubu puan ortalamasının son-test ve izlem-testi ölçümlerinde kontrol grubu puan ortalamasına göre yüksek bulunsa da söz konusu fark istatistiksel olarak anlamlı bulunmamıștır. Kaya vd. (2021) hemşirelik öğrencileri ile 
gerçekleştirdikleri çalışmada psikodrama grubunun öğrencilerin koşulsuz kendini kabulleri üzerinde anlamlı etkisinin olmadığını bulmuşlardır ve bu bulgu çalışma bulgusu ile paralellik göstermektedir. Çalışma bulgusunun aksine, Uzun (2018) üniversite öğrencileri ile gerçekleştirdiği 12 oturumluk psikodrama grubu sonucunda katılımcıların öz şefkat puanlarının arttığını ve kendini yargılama puanlarının azaldığını bulmuştur. Diani ve Siddik (2017) ise, lise son sınıf öğrencileri ile gerçekleştirdikleri psikodrama grubunun öğrencilerin kendini kabul düzeyleri üzerinde pozitif yönde etkisinin olduğunu bulmuşlardır. Alanyazında farklı gruplarda yapılan psikodrama grup uygulamasının katılımcıların öz sevecenlik, öz farkındalık ve benlik saygısı üzerinde pozitif yönde etkisi olduğu bulunurken kendini yargılama ve eleștirme üzerinde negatif yönde etkisinin olduğu bulunmuştur (Bakalım vd., 2018; Doğan 2018; Orkibi vd., 2017). Bu çalışmada da, deney grubundaki katılımcıların koşulsuz kendini kabul puan ortalamalarında artış olsa da bu değişimin anlamlı yönde olmadığı, psikodrama grup uygulamasının katılımcıların kendisi ile ilgili bir farkındalık yaratsa da oturum sayısı ve kısa süreli çalışmaya bağlı olarak bireyin koşulsuz kendini kabul düzeyleri üzerinde anlamlı değişime yol açmadığı düşünülmektedir.

Hemşirelik öğrencileri ile gerçekleştirilen psikodrama grup uygulamasının öğrencilerin PİOÖ alt boyutlarından Diğerleri ile Olumlu İlişkiler, Yaşam Amaçları ve Öz Kabul üzerinde pozitif yönde anlamlı etkisinin olduğu bulunmuştur. Aynı zamanda PİOÖ toplam puan, Pİöö'nün diğer alt boyutlarının ve KKKÖ puan ortalamasının deney grubunda kontrol grubuna göre arttığı ancak bu farklılığın anlamlı yönde olmadığı bulunmuştur. Üniversite yaşantısı, öğrencilerin kendilerini tanıdıkları, yeteneklerini keşfettikleri aileden uzaklaşarak özerkliklerinin geliştiği, yeni rol ve sorumluluklar kazandıkları gelişimsel bir süreçtir. Bu gelişimsel süreç zaman zaman öğrencileri zorlayabilmektedir, bu nedenle öğrencilerin bu dönemde psikolojik iyi oluşlarının artırılması için ruhsal açıdan destekleyici ve güçlendirici uygulamaların gerçekleştirilmesi önemli olacaktır. Aynı zamanda öğrencilerle daha uzun süreli psikodrama grup uygulamalarının gerçekleștirilmesinin öğrencilerin psikolojik iyi oluş ve kendini kabul düzeylerinin artırılmasında etkili olacağı düşünülmektedir. Benzer șekilde psikodrama grup uygulamaları gerçekleștirilirken grupların heterojen özellikte olması grup üyelerinin kendini açma ve kendi süreçlerini çalışması açısından daha cesaretlendirici olacağı düşünülmektedir.

$\mathrm{Bu}$ çalışmanın çeşitli sınırlılıkları bulunmaktadır. İlk sınırlılık, deney grubu ile gerçekleştirilen psikodrama grubunun 10 oturum şeklinde yapılmış olmasıdır. Bu bağlamda, kontrol grubuna göre psikolojik iyi oluş ve kendini kabul düzeyi üzerinde pozitif yönde etkisi olsa da daha uzun süreli gruplar düzenlenmesi önerilmektedir. İkinci bir sınırlılık, bu çalışmada, izlem testi verileri son test verileri toplandıktan iki ay sonrasında toplanmıştır. Gerçekleştirilen psikodrama grubunun uzun dönemli etkisini değerlendirmek için daha uzun aralıklı izlem 
testlerinin uygulanması ve katılımcılar üzerindeki etkisinin değerlendirilmesi önerilmektedir. Üçüncü bir sınırlılık, psikodrama grubu üyeleri aynı hemşirelik okulu ve aynı kültürden gelen öğrencilerinden oluşması ve öğrencilerin birbirleriyle tanışıklıklarının bulunmasıdır. $\mathrm{Bu}$ durumun, üyelerin grup sürecinde kendini açma, duygularını ifade etme ve yaşantılarını paylaşma adına kısıtlayıcı olduğu düşünülmektedir. İleride düzenlenecek grup çalışmalarında grup üyelerinin birbirleriyle tanışıklık düzeylerinin en aza indirilmesinin üyelerin kendini açma ve yaşantılarını paylaşma konusunda daha cesaretlendirici olacağı düşünülmektedir. Son sınırlılık ise, grup yöneticisinin aynı zamanda üyelerin eğiticisi olma rolünün bulunmasıdır. Grup sürecinde her ne kadar eğitici ve yönetici rollerinin ayrıștırılmasına ve grup dışında bırakılmasına yönelik grup oyunu oynanmış olsa da bu durumun üyelerin yaşantı paylaşımı açısından sınırlayıcı olabileceği düşünülmektedir. 


\section{KAYNAKÇA}

Abbasi, M., Ghorbani, N., Imani, A. H., \& Hoseinzadeh, S. T. (2021). Exploring the mediating role of integrative self knowledge in the relationship between mindfullness-based stress reduction program. International Journal of Psychology, 56(2), 249256. https://doi.org/10.1002/ijop.12705

Acun-Kapıkıran, N., \& Kapıkıran, Ş. (2010). Koșulsuz Kendini Kabul Ölçeği'nin Türk üniversite öğrencileri için geçerliği ve güvenirliği. Kriz Dergisi, 18(1), 33- 44. https://doi.org/10.1501/Kriz_0000000309

Akın, A. (2008). Scales of Psychological Well-Being: A study of validity and reliability. Educational Science: Theory \& Practice, 8(3), 721-750.

Aștı, N., Acar, G., Bağcl, H., \& Bağcl, İ. (2005). Sağlık bakım profesyoneli olarak yetişecek öğrencilerin ruhsal durumları ve yaklaşımlar. Muğla Üniversitesi Sosyal Bilimler Enstitüsü Dergisi, 15, 25-35.

Atak, H. (2011). Yetişkinliğe aşamalı geçiş: Beliren yetişkinlik tek bir ana yol mu? Illköğretim Online, 10(1), 51-67.

Bakalım, O., Yörük, C., \& Şensoy, G. (2018). Psikodrama grup yaşantısının rehberlik ve psikolojik danıșmanlık öğrencilerinin öz-duyarlılık düzeylerine etkisi. Elektronik Sosyal Bilimler Dergisi, 17(67), 949-968. https://doi.org/10.17755/esosder.331543

Bewick, B., Koutsopoulou, G., Miles, J., Slaa, E., \& Barkham, M. (2010). Changes in undergraduate students' psychological well-being as they progress through university. Studies in Higher Education, 35(6), 633-645. https://doi.org/10.1080/03075070903216643

Burris, J. L., Brechting, E. H., Salsman, J., \& Carlson, C. R. (2009). Factors associated with the psychological well- being and distress of university students. Journal of American College Health, 57(5), 536-543. https://doi.org/10.3200/JACH.57.5.536-544

Büyüköztürk, Ș. (2016). Deneysel desenler öntest-sontest kontrol grubu desen ve veri analizi. Pegem Akademi Yayıncılık.

Çelik M., Turunç, Ö., \& Bilgin, N. (2014). Çalışanların örgütsel adalet algılarının psikolojik sermaye üzerine etkisi: Çalışanların iyilik halinin düzenleyici rolü. Sosyal Bilimler Enstitüsü Dergisi, 16(4), 559-585. https://doi.org/10.16953/deusbed.25259

Cesur-Atintas, M., \& Kirlangic-Simsek, B. (2020) Examining the effects of psychodrama practice: a study on psychological well-being, hopelessness and insight in emerging adults. $Z$ Psychodrama Soziom, 19(1), 21-31. https://doi.org/10.1007/s11620-020-00560-2

Chamberlain, J. M., \& Haaga, D. A. F. (2001). Unconditional self-acceptance and psychological health. Journal of Rational-Emotive \& Cognitive-Behavior Therapy, 19(3), 163- 176. https://doi.org/10.1023/A:1011189416600

Demirel-Adagide, S., Eğlence, R., \& Kaçmaz, E. (2011). Üniversite öğrencilerinin ruhsal durumlarının belirlenmesi. NEÜ Sosyal Bilimler Enstitüsü Dergisi, 1(1),18-29.

Diani, R. N., \& Siddik, R. R. (2017). The effectivenes of psychodrama technique to increase students' self-acceptance. Analitika: Jurnal Magister Psikologi UMA, 9(2), 97-105. https://doi.org/10.31289/analitika.v9i2.1394

Doğan, T. (2018). The effects of the psychodrama in instilling empathy and self-awareness: A pilot study. PsyCh Journal, 7(4), 227-238. https://doi.org/10.1002/pchj.228

Ellis, A. (1973). Humanistic psychotherapy: The rational-emotive approach. Crown and McGrawHill Paperbacks.

Erdoğan S., Şanlı, S., \& Bekir, H. Ş. (2005). Gazi Üniversitesi Eğitim Fakültesi öğrencilerinin üniversite yaşamına uyum durumları. Kastamonu Eğitim Dergisi, 13(2), 479-496. 
Faustino, B., Vasco, A. B., Silva, A. N., \& Marques, T. (2020). Relationships between emotional schemas, mindfulness, self-compassion and unconditional self-acceptance on the regulation of psychological needs. Research in Psychotherapy, 23(2), 145-156. https://doi.org/10.4081/ripppo.2020.442

Huang, J., Nigatu, Y. T., Smail-Crevier, R., Zhang, X., \& Wang, J. (2018). Interventions for common mental health problems among university and college students: A systematic review and meta-analysis of randomized controlled trials. Journal of Psychiatric Research, 107, 1-10. https://doi.org/10.1016/j.jpsychires.2018.09.018

İlğan, A., Sevinç, Ö. S., Niron, D. G., Kılıç, A., \& Yumuşak, A. (2015). Lisans öğrencilerinin psikolojik iyilik hallerinin YGS puanları ve çeşitli değişkenler ile ilişkisi. Mersin Üniversitesi Eğitim Fakültesi Dergisi, 11(2), 469-486. https://doi.org/10.17860/efd.57173

İlhan, N., Bahadırlı, S., \& Ercan-Toptaner, N., (2014). Üniversite öğrencilerinin ruhsal durumları ile sağlık davranışları arasındaki ilişkinin belirlenmesi. Marmara Üniversitesi Sağlık Bilimleri Enstitüsü $\quad$ Dergisi, $207-215$. https://doi.org/10.5455/musbed.20140913124019

Karataş, Z. (2014). Effects of psychodrama practice on university students' subjective well being and hopelessness. Eğitim ve Bilim, 39(173), 117-128.

Kaya, F. (2020). The effect of psychodrama practice on the subjective well-being in nursing students: A quasi-experimental study. Z Psychodrama Soziom, 19 (1), 255-266. https://doi.org/10.1007/s11620-020-00575-9

Kaya, F., \& Deniz, H. (2020). The effects of using psychodrama on the psychological wellbeing of university students. Perspectives in Psychiatric Care, 56(4), 905-912. https://doi.org/10.1111/ppc.12510

Kaya, Y., Güç, E., Kırlangıç-Şimşek, B., \& Cesur-Atintaş, M. (2021). The effect of psychodrama group practices on nursing students' self-liking, self-competence and self-acceptance: A quassiexperimental study. Perspectives in Psychiatric Care, https://doi.org/10.1111/ppc.12921

Kellermann, P. F. (2013). Psikodramaya derinlemesine bakış: Psikodramanın terapötik yönleri. (Çev. Ed. B. Gökler, I. Gökler-Danışman, \& A. Mavili-Aktaş). Nobel Yayıncılık.

Lee, E., \& Kim, Y. (2019). Effect of university students' sedentary behavior on stress, anxiety, and depression. Perspectives in Psychiatric Care, 55(2), 164-169. https://doi.org/10.1111/ppc.12296

Macinnes, D. L. (2006). Self-esteem and self-acceptance: an examination into their relationship and their effect on psychological health. Journal of Psychiatric and Mental Health Nursing, 13, 483-489. https://doi.org/10.1111/j.1365-2850.2006.00959.x

Manderscheid, R. W., Ryff, C. D., Freeman, E. J., McKnight-Eily, L. R., Dhingra, S., \& Strine, T. W. (2010). Evolving definitions of mental illness and wellness. Preventing Chronic Disease, 7(1), 1-6.

Orkibi, H., Azoulay, B., Snir, S., \& Regev, D. (2017). In-session behaviours and adolescents' selfconcept and loneliness: A psychodrama process-outcome study. Clinical Psycholgy \& Psychotherapy, 24(6), 1455-1463. https://doi.org/10.1002/cpp.2103

Özbek, A., \& Leutz, G. (2011). Psikodrama: Grup psikoterapilerinde sahnesel etkileșim J. L. Moreno'ya göre psikodrama. Ayrıntı Basımevi.

Ryff, C. D. (1995). Psychological well-being in adult life. Current Directions Psychological Science, 4(4), 99-104. https://doi.org/10.1111\%2F1467-8721.ep10772395

Ryff, C. D. (2014). Psychological well-being revisited: Advances in the science and practice of eudaimonia. Psychotherapy and Psychosomatics, 83(1), 10-28. https://doi.org/10.1159/000353263 
Ryff, C. D. (2017). Eudaimonic well-being, inequality, and health: Recent findings and future directions. International Review of Economics, 64(2),159-178. https://doi.org/10.1007/s12232-017-0277-4

Ryff, C. D., \& Singer, B. H. (2008). Know thyself and become what you are: A eudaimonic approach to psychological well-being. Journal of Happiness Studies, 9, 13-39. https://doi.org/10.1007/s10902-006-9019-0

Ryff, C. D., \& Keyes, C. L. M. (1995). The structure of psychological well-being revisited. Journal of Personality and Social Psychology, 69(4), 719-727. https://doi.org/10.1037/00223514.69.4.719

Thompson, B. L., \& Waltz, J. A. (2008). Mindfulness, self-esteem, and unconditional selfacceptance. Journal of Rational-Emotive \& Cognitive-Behavior Therapy, 26 (2), 119-126, https://doi.org/10.1007/s10942-007-0059-0

Tunç, B., Tarsuslu, B., \& Öner, Ö. (2020). Üniversite öğrencilerinde psikolojik danışma süreci: Nitel bir araştırma. Türkiye Bütüncül Psikoterapi Dergisi, 3(5), 194-205.

Uzun, R. B. (2018). Psikodrama uygulamalarının üniversite öğrencilerinde öz-şefkat düzeyine etkisi. [Psikodrama Yeterlilik Tezi] Dr. Abdülkadir Özbek Psikodrama Enstitüsü.

Wheeler, K. (2020). Psikiyatri hemşireliğinde ileri düzey uygulamalar için psikoterapi kanıta dayalı uygulama rehberi. (Çev. Ed. A., Atlı Özbaş, N. Gürhan). Nobel Tıp Kitabevi. 


\section{EXTENDED ABSTRACT}

\section{Introduction}

University life is a developmental process in which individuals gain their professional identity, develop their professional knowledge and skills. However, in university life, individuals not only develop their academic skills, but also discover themselves with the changes that occur in mental and social areas (Atak, 2011; Huang et al., 2018). Although this developmental process is not the same for each individual, some individuals get through this process in a healthier way, while for others, university life can become a developmental crisis. The psychological and social difficulties experienced in this process can negatively affect the psychological well-being of the students. Problems in students' psychological well-being can lead to problems related to university adjustment, academic failure, psychosocial and mental problems if not intervened in the early period (Lee and Kim, 2019; Tunç et al., 2020). Therefore, university students need some preventive mental health practices aimed at getting to know themselves and their abilities, developing a positive self-perception and gaining problem-solving skills (Abbasi et al., 2021; Kaya et al., 2021). One of these preventive mental health practices is psychodrama-based group practices.

\section{Method}

This study was carried out between March and July 2019 in order to evaluate the effect of psychodrama group practice on the psychological well-being and self-acceptance levels of nursing students, and it is a quasi-experimental study in which pre-test, post-test and follow-up-test were applied. Within the scope of the study, the experimental group and the control group started with 16 participants, while two participants in the experimental group left on the grounds that they did not want to continue with the psychodrama group, while one participant in the control group was excluded from the study because they completed the data collection form incompletely. 10 sessions of psychodrama group practice were performed to the participants in the experimental group. Study data were collected with Descriptive Characteristics Questionnaire, Psychological Well-Being Scale (PWBS), and Unconditional Self-Acceptance Scale (USAS). In the analysis of the study data, the Chi-Square Test was used to compare the descriptive characteristics of the experimental and control groups, the Mann-Whitney U Test was used to compare the scale mean score between the groups, and the Friedman and Wilcoxon Signed Rank Test was used to compare the within-group means.

\section{Results}

While the mean age of the participants in the experimental group was $20.57 \pm 1.08$, the participants in the control group were found to be $20.40 \pm 0.91$. The majority of the participants in 
the experimental and control groups were women $(\mathrm{E}=85.7 \%, \mathrm{C}=80.0 \%)$ and second-year students $(E=57.1 \%, C=60.0 \%)$, and their mother's education levels were primary school and below ( $E=92.9 \%, C=86.7 \%$ ) and father's education levels were found to be high school and below (E=92.9\%, $C=100 \%)$. When the mean scores of the experimental and control groups, pre-test, post-test and follow-up-test were compared; it was found that there was no significant difference between the mean score of the total and sub-dimensions of PWBS and the mean score of the total score of USAS ( $p>0.05$ ). It was found that the mean score of the total and sub-dimensions of PWBS and the mean score of the total score of USAS were higher in the experimental group compared to the control group in terms of post-test and follow-up-test mean scores, but this difference was not statistically significant ( $p>0.05$ ). As a result of the Friedman test, which was performed to evaluate whether there was a significant difference between the means within the group, it was found that the mean scores of Positive Relations with Others, Purposes in Life and Self-Acceptance, which are sub-dimensions of the PWBS scale, differed in the experimental group. According to the Wilcoxon Signed Rank Test, which was used to determine which measurement the difference originated from, between the pre-test and post-test for the Positive Relations with Others sub-dimension, between the post-test and follow-up-test for the Purposes in Life sub-dimension, and the pre-test and follow-up-test for the Self-Acceptance sub-dimension $(p<0.05)$.

\section{Discussion \& Conclusion}

It was found that the total and sub-dimension mean scores of nursing students in the psychodrama group practice carried out with the experimental group increased compared to the control group, but this change was not significant. However, it was found that the psychodrama group practice applied to the experimental group had a positive and significant effect over time on the levels of "Positive Relations with Others", "Purposes in Life" and "Self-Acceptance" which are sub-dimensions of PWBS. There are similar results in the literature, and as a result of the psychodrama group practice performed with university students, there are results that the PWBS point averages of the students increased compared to the control group, but it was not statistically significant (Cesur-Atintaş and Kırlangıç-Şimşek 2020; Kaya and Deniz 2020). However, Kaya (2020) in her study evaluating the effect of psychodrama group practice on the subjective wellbeing of nursing students, concluded that psychodrama had a significant effect on students' selfknowledge and their feelings and forming life goals. When the effect of psychodrama group practice on nursing students' USAS was evaluated, although the post-test and follow-up-test mean scores of the experimental group were found to be higher than the control group, this difference was not statistically significant. Similarly, Kaya et al. (2021), in their study with nursing students, they found that psychodrama group practice did not have a significant effect on students' USAS. Contrary to the findings of this study, some studies in the literature found that psychodrama group 
practices had a positive effect on the participants' self-compassion and self-acceptance levels (Diani and Siddik 2017; Uzun, 2018). University life is a developmental process in which students experience stress due to change in many areas. For this reason, there is a need for mentally supportive practices to increase the psychological well-being of students. One of these applications is psychodrama. However, although the 10-session psychodrama group practice in this study had an effect on the students' psychological well-being and self-acceptance levels, this was not statistically significant. For this reason, it is thought that longer-term psychodrama group practices will be effective in increasing students' psychological well-being and self-acceptance levels. 